\title{
OPTIMAL SIZING OF A STAND-ALONE HYBRID RENEWABLE ENERGY SYSTEM SUPPLYING FOR RESIDENTIAL LOAD IN CHUONG MY, HANOI USING HOMER
}

\author{
Nguyen Thi Hoai Thu ${ }^{*}$, Nguyen Huu Tri ${ }^{2}$ \\ ${ }^{1}$ School of Electrical Engineering - Hanoi University of Science and Technology, \\ ${ }^{2}$ Chuong My Power Company
}

\begin{tabular}{r}
\hline ARTICLE INFO \\
\hline Received: $12 / 6 / 2021$ \\
Revised: $12 / 8 / 2021$ \\
Published: $12 / 8 / 2021$ \\
KEYWORDS
\end{tabular}

Optimal sizing

Stand-alone hybrid system

Renewable energy

HOMER software

Sensitivity analysis

\begin{abstract}
In recent years, Vietnam is witnessing a blooming installation of renewable energy sources, namely the photovoltaic and wind turbine system. For the effective applications of the renewable energy sources, one important question is the optimal sizing of the system. In this paper, we evaluated the feasibility of a standalone system supplying to an industrial load and then selected the optimized system using HOMER (Hybrid Optimization Model for Electric Renewable) software. The proposed hybrid system includes PV/wind turbine combined with diesel generator and battery. The system was optimized to meet the residential load of $61849 \mathrm{kWh} /$ day with a $3853.95 \mathrm{~kW}$ peak load demand in Chuong My province. The result shows that the optimal configuration consisted of $7112 \mathrm{~kW}$ PV arrays, $4200 \mathrm{~kW}$ diesel generators, $10947 \mathrm{kWh}$ nominal batteries, and 3284 $\mathrm{kW}$ converters which had the minimum Net Present Cost of \$107 million. Sensitivity analysis was also carried out to evaluate the impact of some economic parameters on the optimal design as well as the Net Present Cost.
\end{abstract}

\section{TỐI ƯU HÓA DUNG LƯợNG CỦA HỆ THỐNG NĂNG LƯợNG TÁI TẠO HỖN HỢP CẤP ĐIỆN CHO PHỤ TẢI SINH HOẠT Ở CHƯỚNG MỸ, HÀ NỘI SỬ DỤNG HOMER}

\author{
Nguyễn Thị Hoài Thu ${ }^{1 *}$, Nguyễn Hữu Trí ${ }^{2}$ \\ ${ }^{1}$ Viện Điện - Truờng Đại học Bách khoa Hà Nội, \\ ${ }^{2}$ Công ty Điện lưc Chuoong Mỹ
}

\begin{tabular}{|c|c|}
\hline THÔNG TII & TÓM TÁ́T \\
\hline Ngày nhận bài: 12/6/2021 & \multirow{10}{*}{ 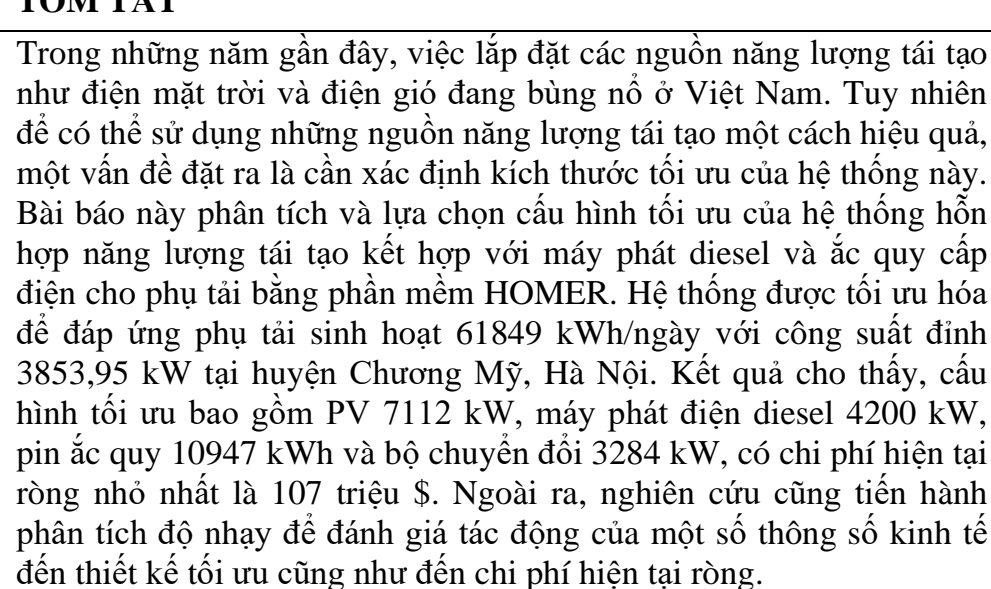 } \\
\hline Ngày hoàn thiện: 12/8/2021 & \\
\hline & \\
\hline & \\
\hline TÙ KHÓA & \\
\hline Dung lượng tối ưu & \\
\hline Hệ thống hỗn hợp độc lập & \\
\hline Năng lượng tái tạo & \\
\hline ần mềm HOMER & \\
\hline Phân tích độ nhạy & \\
\hline
\end{tabular}

DOI: $\underline{\text { https://doi.org/10.34238/tnu-jst.4638 }}$

\footnotetext{
${ }^{*}$ Corresponding author. Email: thu.nguyenthihoai@hust.edu.vn
} 


\section{Introduction}

The development of Vietnam's electricity industry is facing more and more challenges to meet the energy demand for economic growth and to improve people's living standards. Some of the major challenges can be raised as follows: the primary energy sources are gradually exhausted, leading to the need of import fuel; the increasingly strict requirements for environmental issue, ... The development of renewable energy (RE) can be an alternative solution for these challenges. However, the strong development of power sources using RE such as wind and photovoltaic system (PV) also leads to certain difficulties in power system operation [1]. On the other hand, the dependency on the site and the intermittent nature of the weather make these sources difficult to be used as an independent energy provider [2]. Moreover, the oversizing of the components due to the sudden changing of the energy can lead to higher design cost for the system in comparison with the conventional source [3]. Due to the high cost, the issue of optimal sizing of the hybrid system becomes necessary and need to be calculated before planning a project.

In literature, the optimization of different types of hybrid energy system such as PV/Wind, Wind/Diesel, PV/Wind/Diesel, and PV/Diesel generator combined with or without the battery were considered and proven a cost efficient for the off-grid areas. The use of diesel generator as backup power generation along with renewable energy base systems improves the reliability of system and is more beneficial than the stand-alone solar and wind energy system [3], [4]. An analysis on the technical, economic and environmental issue to find out the optimal hybridized system was reported in [3]. However, the sensitivity of cost inputs of different hardware components was not investigated. In [4], the authors investigated a feasibility analysis of PV/Wind/Batt/ Diesel system for the electrification of a remote area. The study indicated that the hybridized system was economically and environmentally feasible compared to the conventional power generation system. The sensitivity analysis of input cost components was also not considered.

As mentioned above, RE has been received more and more attention not only in the world but also in Vietnam. Many RE projects have been developed across the country. However, there are not many studies about the optimal sizing of such a system in Vietnam, especially the analysis on the techno-economic and the emission. Therefore, this paper focuses on the sizing optimization of a stand-alone hybrid PV/wind/battery/diesel system supplying for case study of the residential load in Chuong My province, Hanoi. We also considered the emission of $\mathrm{CO}_{2}$ and examined different types of the hybrid system to compare the optimal configurations. Additionally, the sensitivity analysis on various input parameters on the cost of the energy system as well as the load uncertainty was investigated. The simulation and economic analysis were carried out using Hybrid optimization model for electric renewables (HOMER). The model of PV output power was simulated as a function of the solar irradiance and the temperature [5], [6]. The wind turbine power output and fuel consumption were expressed as similar in [7].

\section{Methodology}

The methodology adopted in this paper included the following steps: modelling the system components, establishing the optimization problem, collecting the load data and the meteorological data, and finally using HOMER for the techno-economic analysis and for sensitivity analysis. The full grid-independent hybrid system under study was shown in Figure 1. PV arrays and a battery were connected to a DC bus while wind turbine, diesel generator and electrical load were connected to an AC bus. Then, the DC system was converted into AC through converter and also connected to the AC bus. Different system components, for example with or without diesel generator were examined and clarified in section 3.

\subsection{System modelling}




\subsubsection{Modelling of PV system}

The model of PV output power can be simulated as the function of the solar irradiance and the temperature [5], [6].

$$
P_{P V}(t)=P_{P V-r} \times \eta_{P V} \times\left(\frac{G(t)}{G_{r e f}}\right) \times\left[1-\beta \times\left(T_{c}-T_{r e f}\right)\right]
$$

where $G(t)$ is the irradiation perpendicular to the surface of the photovoltaic array, $\mathrm{P}_{\mathrm{PV}-\mathrm{r}}$ is the nominal power of the panel, $\eta_{\mathrm{PV}}$ is the efficiency of panels, $\beta_{\mathrm{T}}$ is the photovoltaic temperature coefficient $(0.00485), T_{C}$ is the temperature of the cell under operating condition. $G_{\text {ref, }}, T_{\text {ref }}$ is the irradiation and the cell temperature under standard test conditions $\left(25^{\circ} \mathrm{C}\right)$.

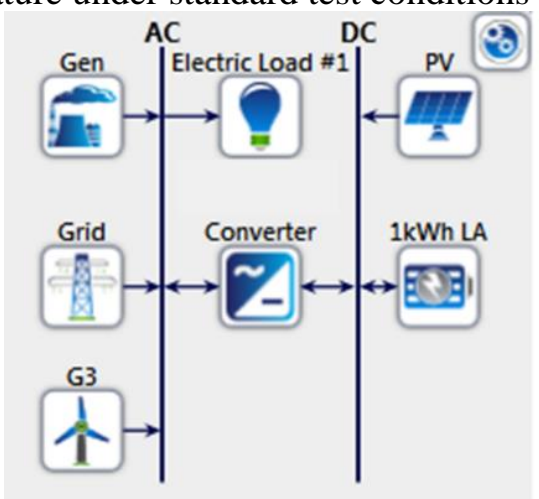

Figure 1. Block diagram of the stand-alone system with full components

\subsubsection{Modelling of Wind turbine system}

The wind turbine power output is expressed as follows [7]

$$
P_{w t}(t)=\left\{\begin{array} { c c } 
{ 0 } & { V ( t ) \leq V _ { i } } \\
{ a \cdot ( V ( t ) ) ^ { 3 } - b \cdot P _ { w - r } } & { V _ { i } < V ( t ) < V _ { r } } \\
{ P _ { w - r } } & { V _ { r } \leq V ( t ) < V _ { o } } \\
{ 0 } & { V ( t ) \geq V _ { o } }
\end{array} \quad \text { where } \quad \left\{\begin{array}{l}
a=\frac{P_{w-r}}{V_{r}^{3}-V_{i}^{3}} \\
b=\frac{V_{i}^{3}}{V_{r}^{3}-V_{i}^{3}}
\end{array}\right.\right.
$$

where $V_{i}(\mathrm{~m} / \mathrm{s})$ is the cut-in speed, $V_{o}(\mathrm{~m} / \mathrm{s})$ is the cut-off speed and $V_{r}(\mathrm{~m} / \mathrm{s})$ is the rated speed of the wind turbine. The rated power is $\mathrm{P}_{\mathrm{w}-\mathrm{r}}(\mathrm{kW})$.

\subsubsection{Modelling of battery}

Battery is integrated in the system to charge the surplus power and discharge the shortage power. The energy in battery can be estimated using following equation

$$
E_{\mathrm{BA}}(t)=E_{\mathrm{BA}}(t-1) \times(1-\sigma)+\left(P_{\mathrm{DCSide}}^{\mathrm{BA} . \mathrm{ch}}(t-1) \times \eta^{\text {ch }} \times \eta_{C O N V}-\frac{P_{\mathrm{DCSide}}^{\text {BA.disch }}(t-1)}{\eta^{\text {disch }} \times \eta_{C O N V}}\right) \times \Delta t
$$

where $\mathrm{E}_{\mathrm{BA}}(\mathrm{t})$ is the energy in the battery at time $\mathrm{t}, P_{\mathrm{DCside}}^{\mathrm{BA} \cdot \mathrm{ch}}(t), P_{\mathrm{DCside}}^{\mathrm{BA} \text {.disch }}(t)$ is the charge and discharge power allocated to the battery at DC bus side of DC/DC converter, $\sigma$ is the selfdischarge rate of the battery $(0.0002), \Delta t$ is time step $(1 \mathrm{~h}) . \eta^{\text {ch }}$ and $\eta^{\text {disch }}$ are the efficiencies of the charge and discharge process $(0.9), \eta^{\mathrm{CONV}}$ are the converter efficiency $(0.95)$.

\subsubsection{Modelling of diesel generator}

When battery is deeply discharged, the insufficient power will be supplied from the diesel generator. The fuel consumption can be modelled as the function of its electrical output as follows [7]:

$$
B(t)=\alpha P_{D G-r}+\beta P_{D G}
$$

where $\alpha$ is the fuel curve intercept coefficient $(0.2461 / \mathrm{kWh}), \beta$ is the fuel curve slope $(0.08145$ $1 / \mathrm{kWh}), P_{D G-r}(\mathrm{~kW})$ is the rated capacity of the generator and $P_{D G}(t)(\mathrm{kW})$ is the electric output of 
the generator at time t. The lower heating value of diesel fuel is $43.2 \mathrm{MJ} / \mathrm{kg}$ with a density of 820 $\mathrm{kg} / \mathrm{m}^{3}[8]$.

Moreover, $\mathrm{CO}_{2}$ will be emitted when the diesel generator operates, the emission can be calculated as follow [8]:

$$
m_{\mathrm{CO}_{2}}=f_{\mathrm{CO}_{2}} \sum_{t=1}^{8760} B(t)
$$

in which $m_{\mathrm{CO} 2}$ is the annual amount of emission (kg/year), $\mathrm{f}_{\mathrm{CO} 2}$ is the emission factor of diesel $(2681 \mathrm{~g} / \mathrm{l})$.

\subsection{Sizing optimization problem}

The objective function of this problem is to determine the optimal configuration of the hybrid system $\left(P_{P V-r}, P_{w-r}, P_{D G-r}, E_{B A-r}, P_{C O N V}\right)$ in order to minimize the Net present cost (NPC). The NPC is the present value of all the costs the system, minus the present value of all the revenue it earns over the project lifetime. In general, the costs include capital costs, replacement costs, operation and maintenance costs and fuel costs.

$$
\begin{gathered}
N P C=C_{\text {equip }} \times C R F+C_{\text {OM }}+C_{\text {Gas }} \\
C R F=\frac{i(1+i)^{N}}{(1+i)^{N}-1}
\end{gathered}
$$

where $\mathrm{C}_{\text {equip }}$ is the annualized capital cost for both the main, auxiliary equipment and replacement cost, $\mathrm{C}_{\mathrm{OM}}$ is the annual operation and maintenance cost, and $\mathrm{C}_{\mathrm{Gas}}$ is the annual cost of fuel consumption for diesel generator. CRF is the capital recovery factor, $\mathrm{i}$ is the interest rate, $\mathrm{N}$ is the project lifetime (25 years). The detail of these costs can be referred in [9], [10]. The economic parameters of equipment were shown in Table 1 [11]. The cost of fuel is $1 \$ /$ litre.

Table 1. Economic parameters of the components

\begin{tabular}{ccccc}
\hline & Capacity & Capital & O\&M & Lifetime \\
\hline PV & $1 \mathrm{~kW}$ & $2500 \$$ & $10 \$ /$ year & 25 years \\
WT & $3 \mathrm{~kW}$ & $18000 \$$ & $180 \$ /$ year & 20 years \\
Batt & $1 \mathrm{kWh}$ & $300 \$$ & $10 \$ /$ year & 10 years \\
CONV & $1 \mathrm{~kW}$ & $300 \$$ & 0 & 15 years \\
DG & autosize & $500 \$ / \mathrm{kW}$ & $0,03 \$ / \mathrm{h}$ & 15000 hours \\
\hline
\end{tabular}

The objective is subject to the following constraints

a. $\quad$ Load balance constraint: $\quad P_{P V}(t)+P_{W T}(t)+P_{\text {Diesel }}(t)+P_{\text {Batt }}(t)=P_{\text {Load }}(t)$

b. $\mathrm{CO}_{2}$ emission constraint: $m_{\mathrm{CO}_{2}} \leq \varepsilon_{\mathrm{CO}_{2} \text { max }}$

c. Constraints of nominal capacity of equipment:

$$
0 \leq P_{P V}(t) \leq P_{P V-r}, 0 \leq P_{w}(t) \leq P_{w-r}, 0 \leq E_{B A}(t) \leq E_{B A-r}
$$

\subsection{HOMER software}

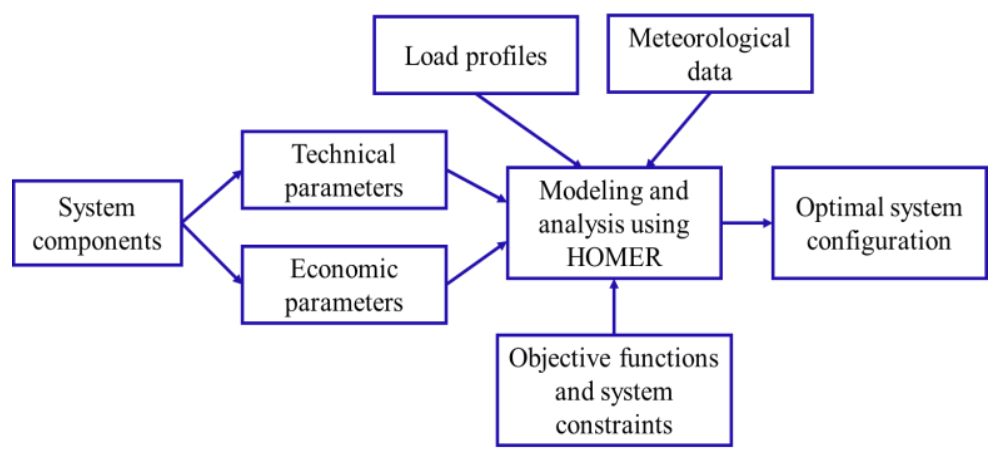

Figure 2. The procedure to design the system using HOMER 
HOMER is a software designed and developed by the US National Renewable Energy Department (NREL) to model, simulate, optimize and sensitize the investigated power system.

HOMER simulates the operation of a system by making energy balance calculations for each of the 8,760 hours in a year for each configuration of the system and then determines the optimal system configuration that is technically feasible within the defined system constraints and has the minimum net present cost. The cost includes the capital and operating cost of the feasible system over the lifetime of the project. The input data such as load profile, solar radiation, the selected site, wind speed data, and technical and economic data of the components involved in the system have to be provided to the software [5].

The procedure to design the system using HOMER was illustrated in Figure 2 [7]. The inputs include the load data, meteorological data of the site, the system components, the objective function, as well as the constraints. Load data was collected and imported by user. The meteorological data, namely the solar irradiation for PV and wind speed for wind turbine of the selected location can be obtained from "NASA surface meteorology and Solar Energy Database". In the system components block, we have to determine which devices are included in the system. The technical and economic parameters of devices can be user-defined or selected from the HOMER database. HOMER will calculate the NPC of the systems and select the optimal configuration with minimum NPC.

\subsection{Load profile}

The proposed system was designed to supply to the residential load of one distribution line in Chuong My province. The typical load was collected and used as input of the system. The load energy and the peak load requirement was calculated to be approximately $61850 \mathrm{MWh} /$ day and $3801.85 \mathrm{~kW}$ respectively. The typical daily electric load profiles of the residential community were illustrated in Figure 3. The load variance throughout 24 hours of a day was clearly shown in the load profiles with the maximum load requirement at night. During the day, most of the family members may not be at home that is why load profile is lower meanwhile at night all the family members will be at home, which leads the load to increase.

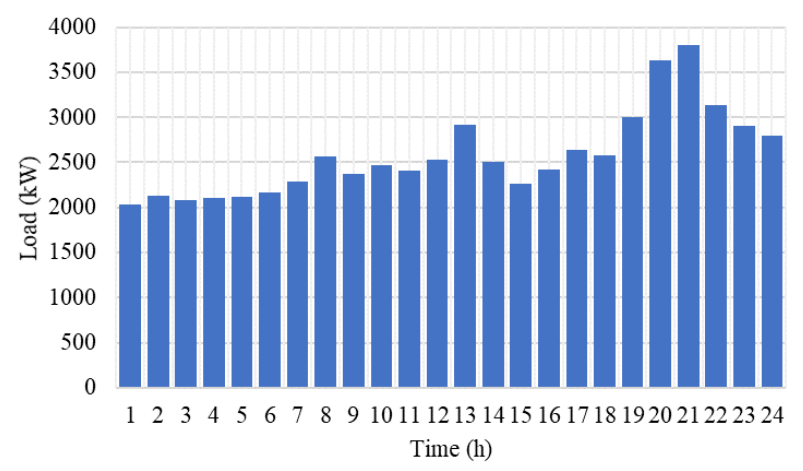

Figure 3. The typical daily residential load of a distribution line in Chuong My, Hanoi

\subsection{Meteorological data}

Solar radiation data was obtained by using HOMER software for the location of Chuc Son, Chuong My at $20.8746^{\circ} \mathrm{N}$ latitude and $105.6712^{\circ} \mathrm{E}$ longitude from "NASA surface meteorology and Solar Energy Database". The annual scaled average solar radiation was found to be 4.030 $\mathrm{kWh} / \mathrm{m}^{2} /$ day and the maximum solar radiation was $4.904 \mathrm{kWh} / \mathrm{m}^{2} /$ day. Data showed that the location had relatively good solar potential and could produce power in efficient way using photovoltaic (PV) panels. A profile indicating solar radiation created by the HOMER for the location was shown in Figure 4 (a). Similarly, wind speed at Chuong My was also acquired by using HOMER and illustrated in Figure 4(b). The annual average wind speed was estimated of 
$3.65 \mathrm{~m} / \mathrm{s}$ and the maximum value was $4.56 \mathrm{~m} / \mathrm{s}$. It can be seen that the wind speed was not really high, so the potential for wind power in this location may be infeasible. We analysed and proved this assessment in the results and discussions.

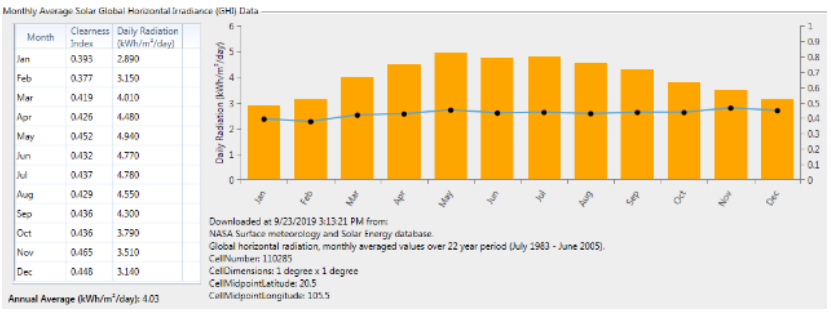

(a)

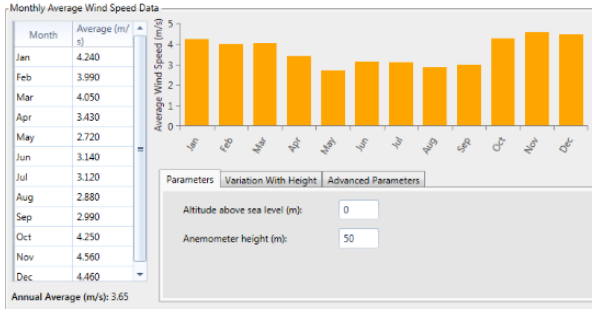

(b)

Figure 4. Solar radiation (a) and wind data (b) in Chuong My, Hanoi

\section{Simulation results and discussion}

\subsection{Base scenarios}

In this study, we optimized the system sizing for 4 different base cases of the system components. The components were included in each scenario as following:

- $\quad$ Case 1: The system includes PV, battery and converter supplying to the load

- $\quad$ Case 2: The system includes wind turbine, battery and converter

- $\quad$ Case 3: The system includes both PV and wind turbine, battery and converter

- Case 4: The system includes not only PV, wind turbine battery and converter but also diesel generator.

For each case, the optimal designing of the system was calculated and presented in Table 2.

It can be seen that in the first case, the optimal result was to use a PV system of $44,840 \mathrm{kWp}$ with $230,648 \mathrm{kWh}$ battery and converters of $7,106 \mathrm{~kW}$. The lowest NPC was considerably high of $278 \mathrm{M} \$$. Because the solar source was available only during daytime while the peak load occurred at night, the system needed a huge battery capacity to response to the load.

Meanwhile in case 2, only wind turbines were used as the primary energy sources, HOMER gave no results. This can be explained by that Chuong My is a place where the wind speed is considerably low with the average value of $3.65 \mathrm{~m} / \mathrm{s}$, just a slightly higher than the cut-in speed of the wind turbine, then this location is not suitable and ineffective for developing wind power.

The result of case 3 was similar to case 1 because as previously analysed, the appearance of wind turbine for this place was infeasible. The load was totally supplied from the PV and battery.

In case 4, the optimized system was composed of 7,112 kW PV, diesel generators of 4,200 $\mathrm{kW}, 10,947 \mathrm{kWh}$ battery and converters of $3,284 \mathrm{~kW}$. It can be seen that the lowest NPC in this case was $107 \mathrm{M} \$$, significantly smaller than the $\mathrm{NPC}_{\mathrm{opt}}$ in case 1 . This is due to the participation of diesel generator to meet the load requirement at night when there is no solar radiation which can decrease the needed sizing of battery and the total cost of the system. It can be noted that diesel generator sizing of $4,200 \mathrm{~kW}$ was quite high. Looking into the load profile, we can see that the peak load occurred at $21 \mathrm{~h}$ meanwhile PV was not available in the evening and at night. Then battery system would provide energy in the evening. If they could supply the peak load, the size might be very high as in case 1, leading to high total cost. Therefore, in this case, the use of diesel generator for peak load was more economic.

\subsection{Sensitivity and uncertainty analysis}

The results of the study were further extended by analysing the sensitivity to investigate the impact of the variation of different input parameters on the optimal sizing and the $\mathrm{NPC}_{\mathrm{opt}}$ of the system. In this study, we examined the change of the following parameters for the system of the case 4 which includes PV/battery and diesel generator: PV panel cost, diesel cost, $\varepsilon_{\mathrm{CO} 2}$ constraint. Additionally, the uncertainty of the load was also considered. 
Table 2. Optimal sizing of the system in 4 cases

\begin{tabular}{cccccccc}
\hline $\begin{array}{c}\text { Base } \\
\text { case }\end{array}$ & $\begin{array}{c}\mathbf{P V}_{\text {opt }} \\
(\mathbf{k W})\end{array}$ & $\begin{array}{c}\mathbf{W T}_{\mathbf{o p t}} \\
(\mathbf{k W})\end{array}$ & $\begin{array}{c}\text { Diesel }_{\text {opt }} \\
(\mathbf{k W})\end{array}$ & $\begin{array}{c}\text { Converter } \\
\mathbf{( k W )}\end{array}$ & $\begin{array}{c}\text { Batt }_{\text {opt }} \\
(\mathbf{k W h})\end{array}$ & $\begin{array}{c}\mathbf{N P C}_{\text {opt }} \\
\mathbf{( \$ )}\end{array}$ & $\begin{array}{c}\text { RE } \\
\text { fraction }\end{array}$ \\
\hline Case 1 & 44,840 & 0 & 0 & $\begin{array}{c}7,106 \\
\text { No result }\end{array}$ & 230,648 & $278 \mathrm{M}$ & $100 \%$ \\
Case 2 & & & & & & \\
Case 3 & 44,840 & 0 & 0 & 7,106 & 230,648 & $278 \mathrm{M}$ & $100 \%$ \\
Case 4 & 7,112 & 0 & 4,200 & 3,284 & 10,947 & $107 \mathrm{M}$ & $36.4 \%$ \\
\hline
\end{tabular}

\subsubsection{Scenario 1: PV cost decreases}

When the PV technology is more and more developing, the PV cost will decrease. Thus, we examined the scenario of the PV capital cost halved. In this scenario, the optimal sizing of PV and battery increased. The size of diesel generator, however, was unchanged to response to the peak load at night meanwhile the battery did this task during time of no solar irradiation before this peak time, similar to the base case. The $\mathrm{NPC}_{\mathrm{opt}}$ decreased from $107 \mathrm{M} \$$ to $94.1 \mathrm{M} \$$ and the rate of renewable energy, namely the PV, increased from $36.4 \%$ to $44.7 \%$.

\subsubsection{Scenario 2: Diesel cost increased 50\%}

Contrary to the PV cost, the price of diesel trends to increase. In the scenario of the price of diesel raised of 50\%, although the size of DG was still unchanged, the size of PV and battery also increased. We witnessed a slightly rise of the RE fraction from $35.4 \%$ to $37.6 \%$ with a higher $\mathrm{NPC}_{\text {opt }}$ of $133 \mathrm{M} \$$.

\subsubsection{Scenario 3: Constraint of $\mathrm{CO} 2$ decreased to $50 \%$ and there was no constraint}

In the base case, the emission of $\mathrm{CO}_{2}$ was limited to $12 \mathrm{Mkg} / \mathrm{year}$, in this scenario, we would change the constraint of emission to $6 \mathrm{Mkg} / \mathrm{year}$ and to no constraint. When the emission was halved, the use of DG was limited and the fraction of RE increased to nearly $100 \%$ as in the base case 1 , then the $\mathrm{NPC}_{\mathrm{opt}}$ soar to $276 \mathrm{M} \$$. On the other hand, when there was no constraint of emission, due to the high capital cost of PV, the proportion of RE would decrease and supply only $1.08 \%$ of needed energy.

\subsubsection{Scenario 4: Load uncertainty of $10 \%$}

In the base case 4, we had not considered the uncertainty of load, meaning that the load was deterministic during the simulation. However, in fact the load could not be exactly predicted, the uncertainty should be examined. With the uncertainty of $10 \%$, the ratio of RE was slightly declined to $34.4 \%$. The size of DG rose to $5,800 \mathrm{~kW}$ to meet the new peak demand.

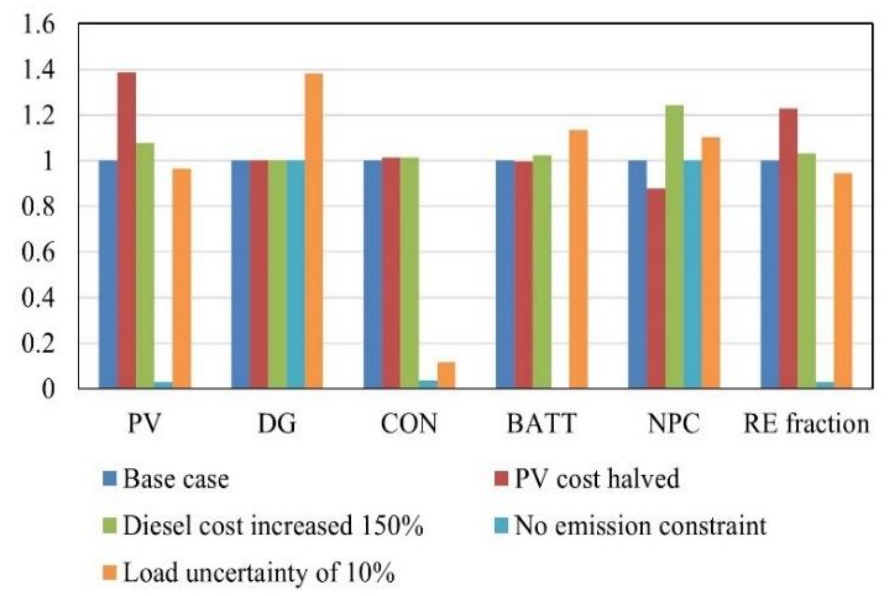

Figure 5. Optimal sizing comparison for sensitivity analysis 
The details of the above sensitivity analysis were shown in Table 3 and Figure 5. In Figure 5, the comparison of the optimal components sizing in 4 scenarios with the base case 4 was presented in which the base case sizing was considered as base value of 1 , the other sizing scenarios were calculated in relative value by dividing the size to the base.

Table 3. Optimal sizing of components when the input parameters changed

\begin{tabular}{ccccccc}
\hline Components & $\begin{array}{c}\text { Base } \\
\text { case }\end{array}$ & $\begin{array}{c}\text { PV cost } \\
\text { halved }\end{array}$ & $\begin{array}{c}\text { Diesel cost } \\
\text { increased } \\
\mathbf{1 5 0 \%}\end{array}$ & $\begin{array}{c}\mathbf{C O}_{2} \\
\text { constraint } \\
\text { halved }\end{array}$ & $\begin{array}{c}\text { No CO2 } \\
\text { constraint }\end{array}$ & $\begin{array}{c}\text { Load } \\
\text { uncertainty of } \\
\mathbf{1 0 \%}\end{array}$ \\
\hline $\mathrm{PV}_{\text {opt }}(\mathrm{kW})$ & 7,112 & 9,860 & 7,666 & 44,750 & 201 & 6,857 \\
$\mathrm{DG}_{\text {opt }}(\mathrm{kW})$ & 4,200 & 4,200 & 4,200 & 4,200 & 4,200 & 5,800 \\
$\mathrm{CONV}_{\text {opt }}(\mathrm{kW})$ & 3,284 & 3,327 & 3,331 & 4,807 & 123 & 383 \\
$\mathrm{BATT}_{\text {opt }}(\mathrm{kWh})$ & 10,947 & 10,918 & 11,223 & 238,256 & 0 & 12,409 \\
$\mathrm{NPC}_{\text {opt }}(\mathrm{M} \$)$ & 107 & 94.1 & 133 & 276 & 107 & 118 \\
$\mathrm{RE}_{\text {fraction }}(\%)$ & 36.40 & 44.70 & 37.60 & 99.20 & 1.08 & 34.40 \\
\hline
\end{tabular}

\section{Conclusion}

In this paper, a comprehensive techno-economic-environmental analysis was carried out to find out the optimal design of an off-grid hybrid system of RE/battery and diesel supplying to the residential load in Chuong My, Hanoi. The results showed that wind power was infeasible for this location. The combination of RE/battery system with diesel generator had the lower NPC than the only source of RE and battery. However, with the strict constraint of emission, the participation of DG would be limited. Moreover, from the sensitivity analysis result, it can be seen that the constraint of emission and the capital cost of PV would significantly impact on the $\mathrm{RE}$ share ratio. With the downtrend of PV cost, the development of PV system is feasible.

\section{REFERENCES}

[1] Institute of Energy, "National Electricity development Planning for 2021-2030 vision to 2045," p. 843.

[2] A. Brka, Y. M. Al-Abdeli, and G. Kothapalli, "Predictive power management strategies for stand-alone hydrogen systems: Operational impact,” Int. J. Hydrog. Energy, vol. 41, no. 16, pp. 6685-6698, May 2016, doi: 10.1016/j.ijhydene.2016.03.085.

[3] M. Mehrpooya, M. Mohammadi, and E. Ahmadi, "Techno-economic-environmental study of hybrid power supply system: A case study in Iran," Sustain. Energy Technol. Assess., vol. 25, pp. 1-10, Feb. 2018, doi: 10.1016/j.seta.2017.10.007.

[4] SK.A.Shezana, S.Julai, M.A.Kibria, K.R.Ullah, R.Saidur, W.T.Chong, and R.K.Akikur, "Performance analysis of an off-grid wind-PV (photovoltaic)-diesel-battery hybrid energy system feasible for remote areas," J. Clean. Prod., vol. 125, pp. 121-132, Jul. 2016, doi: 10.1016/j.jclepro.2016.03.014.

[5] D. N. Luta and A. K. Raji, "Optimal sizing of hybrid fuel cell-supercapacitor storage system for offgrid renewable applications," Energy, vol. 166, pp. 530-540, Jan. 2019, doi: 10.1016/j.energy.2018.10.070.

[6] N. T. H. Thu, "Sizing optimization of a Photovoltaic/Battery system based on analysis of the annual total solar radiation in the north of Vietnam," TNU J. Sci. Technol., vol. 225, no. 13, Aug. 2020, doi: 10.34238/tnu-jst.3367.

[7] S. Mandal, B. K. Das, and N. Hoque, "Optimum sizing of a stand-alone hybrid energy system for rural electrification in Bangladesh," J. Clean. Prod., vol. 200, pp. 12-27, Nov. 2018, doi: 10.1016/j.jclepro.2018.07.257.

[8] HOMER Energy, "HOMER2_2.8_HelpManual.pdf.", Jan 16, 2015. [Online]. Available: https://www.homerenergy.com/pdf/HOMER2_2.8_HelpManual.pdf [Accessed: Jun. 11, 2021]

[9] B. K. Das, N. Hoque, S. Mandal, T. K. Pal, and M. A. Raihan, "A techno-economic feasibility of a stand-alone hybrid power generation for remote area application in Bangladesh," Energy, vol. 134, pp. 775-788, Sep. 2017, doi: 10.1016/j.energy.2017.06.024. 
[10] V. Khare, S. Nema, and P. Baredar, "Optimization of hydrogen based hybrid renewable energy system using HOMER, BB-BC and GAMBIT," Int. J. Hydrog. Energy, vol. 41, no. 38, pp. 16743-16751, Oct. 2016, doi: 10.1016/j.ijhydene.2016.06.228.

[11]R. Rajbongshi, D. Borgohain, and S. Mahapatra, "Optimization of PV-biomass-diesel and grid base hybrid energy systems for rural electrification by using HOMER,” Energy, vol. 126, pp. 461-474, May 2017, doi: 10.1016/j.energy.2017.03.056. 